\title{
Importance of Soil Science in the European Green Deal Congress inauguration statement
}

\author{
Carmelo Dazzi \\ President of the European Society for Soil Conservation \\ University of Palermo, Italy \\ Email: carmelo.dazzi@unipa.it
}

\begin{abstract}
This is the Congress inauguration statement of Professor Carmelo Dazzi (President of the European Society for Soil Conservation) to the international conference "Sustainable Management of Cultural Landscapes in the context of the European Green Deal", held in Santo Stefano di Camastra (Sicily, Italy) jointly organized by the European Society for Soil Conservation and the European Ecocycles Society on November 9-14, 2021.
\end{abstract}

Keywords - Congress inauguration statement, Professor Carmelo Dazzi, International Congress, "Sustainable Management of Cultural Landscapes in the context of the European Green Deal"

Political and Academic Authorities, Distinguished

Colleagues,

Ladies and Gentlemen, Dear Friends, ${ }^{1}$

It is a great honor to welcome you personally, and on behalf of the European Society for Soil Conservation.

I would like to begin these welcome words by expressing my most sincere thanks to the Authorities, Representatives, and Delegates from the institutions and companies that have helped with the organization of this international congress, as well as everyone else who is here today with us at this opening ceremony.

We have had a lot of help and support in organizing this international congress.

In particular, I wish to underscore the support of the municipality of Santo Stefano di Camastra (mainly the

\footnotetext{
${ }^{1}$ Presented at the "Sustainable Management of Cultural Landscapes in the context of the European Green Deal", International Congress, held in Santo Stefano di Camastra (Sicily, Italy) on November 9-14, 2021.
}

major and the whole city council), and the support of the Nebrodi Natural Park (mainly the president, the director, and the whole staff of the park).

The European Society for Soil Conservation was founded in Ghent, Belgium in 1988 by a small group of researchers from various European countries. The activity of the Society in the organization and support of scientific meetings, the backing of soil conservation studies, the publication of surveys, reports, and documents, the cooperation with institutions and with persons on conservation initiatives, are all things we greatly value, and of which we are proud. The organization of this joint congress is an example.

In the future years, the socio-economic development and the maintenance of human well-being will largely depend on the sustainable use of resources, a task very complex due to changes in human activities that impact the environment and in particular on the soilscapes. We live in an age and in a cultural system that pays particular attention to the protection of human rights, but that does not indicate duties and responsibilities. We can fight to defend our privileges, but we defile our duties. Our relationship with the environment is characterized by a general indifference and a widespread carelessness and the awareness of the role that plays the environmental resources, in particular the soils, is 
lacking. The importance of this latter, being a "cryptoresource", a hidden resource, is considered only when occur catastrophic events. At the European level, a comprehensive and coherent policy framework for soil conservation and protection is still lacking. Consequently, the current challenge of the scientific community is to organize research to find solutions to the environmental and social problems of our time, stimulating interdisciplinary collaboration and facilitating the dialogue between researchers who have a different cultural background but share the same objectives and similar perspectives.

Social progress, the development of schools of thought, as well as the knowledge and the scientific approaches toward a sustainable environment, lead us to rethink old and new challenges with broader and intertwined aims, taking up the continuous process of review and criticism of scientific methods.

It is in this context that we are looking at the role and functions of the soilscapes in the natural systems, and mainly at the functional optimization of the soilscapes in a perspective of sustainable development of the landscapes and protection of the environment.

Soils constitute the path of life on the surface of the planet and provide for the multiple assets, services, and functions of society. Soils are usually considered as non-renewable natural resources because their rate of formation over time is generally low or very low (Stockman et al., 2014) over a human lifetime. They are crucial to life on Earth and play a central role in many of today's environmental challenges (Weil and Brady, 2017). Even so, almost everywhere, soils show evident problems of degradation (Amundson et al., 2015; FAO 2015) due to several threats that undermine their ability to produce goods and services. In the last two decades, and, in particular, after the proposal to set up a World Soil Day celebration that was launched by the International Union of Soil Sciences (IUSS) during its $17^{\text {th }}$ World Congress on Soil Science (Bangkok, Thailand, 2002), the awareness that soils are very important and multifaceted resources has noticeably increased. They are known to perform a leading role in ecological sustainability, climate change mitigation, ecosystem services, land use and planning as well as in food security (Adhikari and Hartemink, 2016; Bampa et al., 2019; Dazzi et al., 2019; Hou et al.. 2020; Yang et al. 2021).

Increasing soil awareness and governance can be seen as a common action that should involve civil society in all the world's countries. This is particularly true for the European Countries, where problems of soil degradation and desertification are evident and acute in many areas (FAO, 2015).

At the international level, in 2011, FAO created the "Global Soil Partnership" (GSP), to promote sustainable soil management and soil protection. The $68^{\text {th }}$ UN General Assembly declared 2015 the International Year of Soils, intending to increase awareness and understanding of the importance of soil for food security and essential ecosystem functions. Besides, to increase this momentum and the extent of the contributions of the civil society on these issues, the International Union of Soil Sciences (IUSS), at the end of 2015, proclaimed the International Decade of Soils 2015-2024.

At the European level, the $7^{\text {th }}$ Environment Action Programme (EAP), which entered into force in January 2014, recognizes that degradation, fragmentation, and unsustainable use of land is consuming fertile soils, jeopardizing the provision of several key ecosystem services, threatening biodiversity, exacerbating soil degradation and desertification and resulting in impacts on global soil and food security (European Union, 2014b)

It is to underline that the Common Agricultural Policy (CAP) also acknowledges that there is a strong feedback between the soil threats (FAO, 2017) and stressors that a holistic and collaborative approach to soil management and governance is crucial, and it has put in place various instruments to promote sustainable use and management of soils (Pe'er et al., 2019).

For the same purposes, the European Commission (EC), has planned the achievement of several important goals in the Zero Pollution action plan (European Commission, 2020a) in the Biodiversity Strategy 2030 (European Commission, 2020b), the Farm to Fork strategy (European Commission, 2020c), the European Climate Law (European Commission, 2020d), the Soil Health and Food Mission (European Commission, 2020e) and the Biodiversity Strategy (European Commission, 2020f). Soil is expressly cited in all the above-reported strategies and/or action plans and is indirectly relevant for achieving climate neutrality in 2050 (Montanarella and Panagos, 2021).

Always in the last two decades, together with the abovelisted initiatives, specific concepts and ideas have been highlighted, aiming to increase the awareness of the soil's importance and role. We refer to the concepts of soil security, soil sustainability, and soil ecosystem services (SESs), as well as the launch of the Sustainable Development Goals (SDGs). It is also important to note that several soil-awareness and education initiatives were planned for informing decision-makers and working with stakeholder groups (Harrison et al., 2005; Towers et al., 2010).

The way we use the landscape and its soils could give a big hand in mitigating global warming. The last report on "Climate Change and Land" of the IPCC (2019), draws a future of floods, droughts, and deserts that devour green areas. The report shows that about a quarter of greenhouse gas emissions comes from the misuse of the landscapes. To respect the agreements of Paris is not enough to cut emissions. We need to reduce deforestation, increase reforestation, practice sustainable agriculture, and consume less soil. 
The Mediterranean climate has already changed. Two weeks ago, we experienced a "medicane", a Mediterranean hurricane. Heatwaves and extreme events increasingly lead to soil degradation and desertification. The drought is increasingly affecting southern Europe along with many poor areas of the world.

The IPCC report points the finger at the cancellation of green areas like marshes, pastures, mangroves, and forests, the "lungs of the planet". In addition, stresses the importance of the food chain. One-third of the products are lost or thrown and are responsible for up to $10 \%$ of emissions in the food system. This will produce more conflicts and migrations, with enormous social costs because arable soils will expand more and more to the North, while in tropical and subtropical areas we will have more droughts and desertification.

We need to change our relationship with the environment.

The European Green Deal (EGD) is a major policy step towards a sustainable society and acknowledges the central role soils play in solving or minimizing most of the environmental problems of our time (Montanarella and Panagos, 2021).

At the European level, the meaning of the Green New Deal is that of a response - with concrete measures - to the emergency due to climate change. For the first time, a law binding on all the European countries has established the achievement of neutrality of pollutant emissions by 2050 .

The Green Deal rules are intended to facilitate a fair and equitable transition to a sustainable economy with zero environmental impact in all Member States. The focus is on achieving a balanced transformation that does not leave behind any citizens and regions in Europe.

To maintain our levels of progress and development, we are forced to a radical change on environmental, social, and economic approaches and attitudes, and to seek out social innovations and different ways to live for not to repeat the mistakes of the past.

The European Green Deal is the new European growth strategy that requires a new mindset to put sustainability at the heart of the way in which we program our development. Consequently, only a careful and prudent change in the way we behave with the soilscapes that support us will allow us to face the global challenge caused by ourselves. This is the reason why the title of the congress is focused on the sustainability of cultural landscapes, and there is a clear reference to the European Green Deal.

Indeed, the recently presented EU Soil Strategy for 2030 (European Commission 2021), will significantly contribute to several of the objectives of the Green Deal and objectives prior to that.
In particular, the medium-term objectives by 2030 are:

- Combat desertification, restore degraded land and soil, including land affected by desertification, drought and floods, and strive to achieve a land degradation-neutral world.

- $\quad$ Significant areas of degraded and carbon-rich ecosystems, including soils, are restored.

- $\quad$ Achieve an EU net greenhouse gas removal of 310 million tonnes $\mathrm{CO} 2$ equivalent per year for the land use, land-use change, and forestry (LULUCF) sector.

- Reach good ecological and chemical status in surface waters and good chemical and quantitative status in groundwater by 2027.

- $\quad$ Reduce nutrient losses by at least $50 \%$, the overall use and risk of chemical pesticides by $50 \%$, and the use of more hazardous pesticides by $50 \%$ by 2030 .

- Significant progress has been made in the remediation of contaminated sites.

And the long-term objectives by 2050 :

- $\quad$ Reach no net land take.

- $\quad$ Soil pollution should be reduced to levels no longer considered harmful to human health and natural ecosystems and respect the boundaries our planet can cope with, thus creating a toxic-free environment.

- $\quad$ Achieve a climate-neutral Europe25 and, as the first step, aim to achieve land-based climate neutrality in the EU by 2035 .

- $\quad$ Achieve for EU a climate-resilient society, fully adapted to the unavoidable impacts of climate change by 2050 .

We are a scientific society, not a political group. Our tools are the findings of scientific research, and we use these findings to generate and to give information as well as knowledge about our natural resources.

We must be so clever to be able to propose guidelines and courses of action to society, which will contribute to effective and sustainable use of the landscape and its natural and cultural resources.

This Congress is on the way to being a great opportunity to pay special attention to the new challenges and opportunities concerning the contribution of the sustainable management of the cultural landscapes in reaching the aims of the European green deal.

Let us consider this magnificent small city, which pays particular attention to sustainable development, like a 
lighthouse to guide us in the pursuit and the deepening of our knowledge about our environment, with a critical and rigorous stance, also considering new bold and creative approaches.

And, to conclude this welcome speech, let me say that Covid divided us, but it's wonderful to meet again all together. I am very happy about this.

Thank you very much again, and on behalf of the European Society for Soil Conservation, enjoy the congress!

\section{REFERENCES}

Amundson, R., Berhe, A.A., Hopmans, J.W., Olson, C., Sztein, A.E., \& Sparks, D.L. (2015). Soil and human security in the 21 st century. Science 348 .

DOI: $\underline{10.1126 / \text { science. } 1261071}$

Bampa, F., O'Sullivan, L., Madena, K., Sandén, T., Spiegel, H., Henriksen, C. B., Ghaley, B. B., Jones, A., Staes, J., Sturel, S., Trajanov, A., Creamer, R. E., \& Debeljak, M. (2019). Harvesting European knowledge on soil functions and land management using multi-criteria decision analysis. Soil Use and Management, 35(1), 6-20.

DOI: $\underline{10.1111 / \text { sum. } 12506}$

Dazzi, C., Galati, A., Crescimanno, M., \& Lo Papa, G. (2019). Pedotechnique applications in large-scale farming, Economic value, soil ecosystems services and soil security. Catena 181. 104072.

DOI: $\underline{10.1016 / \text { j.catena.2019.104072 }}$

European Commission (2020a). EU Action Plan. Towards a Zero Pollution Ambition for air, water and soil https://ec.europa.eu/info/law/better-regulation/have-yoursay/initiatives/12588-EU-Action-Plan-Towards-a-ZeroPollution-Ambition-for-air-water-and-soil

European Commission (2020b). EU Biodiversity Strategy for 2030. Bringing nature back into our lives. COM (2020) 380 final. Brussels.

European Commission (2020c). Farm to Fork Strategy. For a fair, healthy and environmentally friendly food system https://ec.europa.eu/food/sites/food/files/safety/docs/f2f acti on-plan_2020_strategy-info_en.pdf

European Commission (2020d). Proposal for a Climate Law, COM (2020) 80 final. Brussels.

https://eur-lex.europa.eu/legal-

content/EN/TXT/PDF/?uri=CELEX,52020PC0080\&from= $\underline{\text { EN }}$

European Commission (2020e). Mission area, Soil health and food.

https://ec.europa.eu/info/horizon-europe/missions-horizoneurope/soil-health-andfood en\#, ,text=A\%20 mission\%20in\%20the\%20area,soil $\%$ 20health $\% 20$ and $\% 20$ soil $\% 20$ functions
European Commission (2020f). Communication from the commission to the European parliament, the council, the European economic and social committee and the committee of the regions EU Biodiversity Strategy for 2030. Bringing nature back into our live, Brussels, 20.5.2020. COM(2020) 380 final.

European Commission (2021). Communication from the commission to the European parliament, the council, the European economic and social committee, and the committee of the regions. EU Soil Strategy for 2030. Reaping the benefits of healthy soils for people, food, nature and climate. Brussels, $\operatorname{COM}(2021) 699$ final

European Union (2014). General Union Environment Action Programme to 2020. Living well, within the limits of our planet. Luxembourg, Publications Office of the European Union. 87 pp. ISBN 978-92-79-34724.

FAO (2015). Status of the World's Soil Resources, Main Report. FAO, Rome. ISBN, 978-92-5-109004-6. 650 pp, 2015.

FAO (2017). Voluntary Guidelines for Sustainable Soil Management. Food and Agriculture Organization of the United Nations. Rome, Italy, 26 pp.

Harrison, R., Strahm, B., \& Yi, X. (2005). Soil Education and Public Awareness - Crop and Soil Sciences - Vol.III (C) Encyclopedia of Life Support Systems (EOLSS).

IPCC, 2019: Summary for Policymakers. In: Climate Change and Land: an IPCC special report on climate change, desertification, land degradation, sustainable land management, food security, and greenhouse gas fluxes in terrestrial ecosystems [P.R. Shukla, J. Skea, E. Calvo Buendia, V. Masson-Delmotte, H.- O. Pörtner, D. C. Roberts, P. Zhai, R. Slade, S. Connors, R. van Diemen, M. Ferrat, E. Haughey, S. Luz, S. Neogi, M. Pathak, J. Petzold, J. Portugal Pereira, P. Vyas, E. Huntley, K. Kissick, M. Belkacemi, J. Malley, (eds.)]

Montanarella L., \& Panagos P. (2021). The relevance of sustainable soil management within the European Green Deal. Land Use Policy.

DOI: $10.1016 /$ j.landusepol.2020.104950

Pe'er, G., Zinngrebe, Y., Moreira, F., Sirami, C., Schindler, S., Müller, R., Bontzorlos, V., Clough, D., Bezák, P., Bonn, A., Hansjürgens, B., Lomba, A., Möckel, S., Passoni, G., Schleyer, C., Schmidt, J., Lakner, S. (2019). A greener path for the EU Common Agricultural Policy. Science 365(6452), 449-451.

DOI: $\underline{10.1126 / \text { science.aax } 3146}$

Stockman, U., Minasny, B., \& McBratney, A.B, (2014). How fast does soil grow? Geoderma 216, 48-61.

DOI: $\underline{10.1016 / \text { j.geoderma.2013.10.007 }}$ 
Towers, W., Creamer, R., Broll, G., Darboux, F., Duewel, O., Hallett, S.H., Houskova, B., Jones, A., Lobnik, F., Micheli, E., Zdruli, P. (2010). Soil Awareness and Education: Developing a pan European Approach, 19th World Congress of Soil Science, Soil Solutions for a Changing World. Brisbane, Australia. August 2010. Eds Gilkes, R.J.; Nattaporn Prakongkep

Weil, R.R., \& Brady, N.C. (2017). The Soils around Us. In the book, The Nature and Properties of Soils Ed.15th;
Chapter, One. Publisher, Pearson Education, Inc. ISBN-13, 978-0133254488.

Yang, S., Zhao, W., Liu, Y., Cherubini, F., Fu, B., \& Pereira, P. (2021). Prioritizing sustainable development goals and linking them to ecosystem services, A global expert's knowledge evaluation. Geography and Sustainability 1, 321-330.

DOI: $10.1016 /$ j.geosus.2020.09.004

(C) 2021 by the author(s). This article is an open access article distributed under the terms and conditions of the Creative Commons Attribution (CC BY) license (http://creativecommons.org/licenses/by/4.0/). 